European Commission

\section{Framework to be scaled down}

AmBitious plans for a major expansion of European research and development are cut back by 30 per cent in the latest proposals from the European Commission. The European "framework programme" was to have cost in excess of

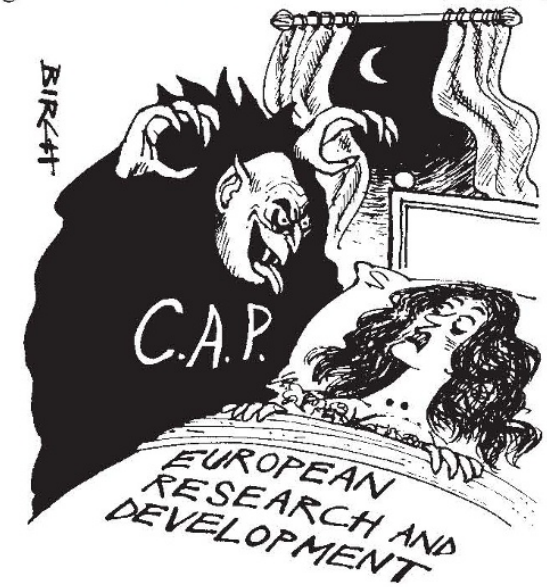

10,000 million ECU (over $£ 15,000$ million). But European research ministers, meeting in June, protested when they saw the budget was more than double the cost of research at present being sponsored by the Commission.

Commission officials had hoped for better progress on the Common Agricultural Policy (CAP), which absorbs more than two-thirds of total Commission spending in farmers' subsidies. If CAP had been trimmed, that could have left room for a larger research programme, now representing only 2 per cent of national research and development budgets. Instead, CAP has grown, the Commission budget has been pushed to its legal ceiling (1.4 per cent of member states' value added tax receipts), and smaller programmes have little chance of gaining extra funds.

Commission research, mostly performed in national, university or industrial laboratories, is strongest in energy (including nuclear fission safety research and fusion), the environment, information and communications technologies, biotechnology (particularly in relation to agricultural change and development), new materials, optical computing and technologies thought likely to revive old industries. Its objective is to unite European research groups on long-term projects and reduce duplication in national programmes. The framework programme is designed to set priprities for the next five years. Two years ago, when planning began, major expansion seemed both politically and financially possible. Now that CAP has eaten the cupboard bare, the Commission's research directorate must hope that increasing political interest in technological cooperation in
Europe will generate support. There is plenty of competition, however, from independent projects such as Eureka aimed at stimulating Europe's hightechnology industries.

The new price-tag for the framework programme is 7,735 million ECU. The adjustments have been made to balance the differing national interests expressed at the last research council meeting: West Germany is reluctant to go into joint telecommunications research, where its principal company, Siemens, feels it has more to lose than to gain, while the British insist on continous programme assessment by outside experts.

Newer activities, such as information technology for the disabled, where the Commission has less experience, are also being cut back. A programme for research on "intelligent transport", involving advanced computers and communications in road vehicles has been cut because of strong overlap with a Eureka programme. New technologies for old industries are also out of favour. But energy research sees a slight increase in response to the
Rehovot

US MEDICAL students at Tel Aviv University pay tuition fees of $\$ 15,000$ a year, a lot more than their Israeli counterparts, who pay only $\$ 900$ (a remarkably low sum decided on by the government). Yet there are far more US applicants for the programme in Tel Aviv than can be accepted, says Yehuda Bar-Shaul, rector of the university. That, he says, is because "the special English-language course at $\mathrm{Tel}$ Aviv is not like those of the dubious "offshore universities' which many American students attend". The Tel Aviv institution has the status of a New York state medical school, and participants in the course who come from New York have more than 40 per cent of their tuition paid for by the state. Moreover, after graduation, the students do their residency in New York hospitals, "and the very best ones at that", the rector adds with pride.

Each year, Tel Aviv University's Sackler Medical School takes in some 60 students from the United States and about 80 from Israel. The US intake causes resentment among Israelis whose applications are rejected and who must therefore go to Italy or Rumania in order to study medicine, but, Ben-Shaul says, there is no justification for such resentment. "Even if this special programme were abolished", he declares, "we would not accept more local students because the 300 new doctors
Chernobyl disaster. The whole of the Commission's nuclear fission research programme, much of it at the Commission's own Ispra laboratory in northern Italy, is now concerned with nuclear safety.

Will member states support the new proposals for the programme? Britain, whose technology minister Mr Geoffrey Pattie will be influential as he chairs the council of research ministers until the end of this year, believes there is room for an increase in total research spending, but not such a substantial one as the Commission is requesting, even in its revised budget. Commission officials certainly believe the larger member states, which pay most of the Commission's bills, are going to be reluctant, but will argue that everybody's long-term interests will be served by improving European cooperation in this area. Britain, however, with its reseach community in revolt at low levels of support at home, will be nervous about the impact of increased international spending on its national research budgets, a matter which is not entirely in Pattie's control. But with the Commission's final proposals now in the hands of national governments, real negotiation can begin.

Robert Walgate

\title{
Medical schools seek US students
}

who graduate each year from the country's four medical schools are more than sufficient to meet Israel's needs."

The example set by Tel Aviv University over the past six years is to be copied by two other major institutions. A few weeks ago, the Haifa Technion decided in principle to begin a similar scheme at its own medical school. But Technion officials speak of fulfilling a Zionist mission, since most of those who would come to study in Haifa are likely to be Jews (as is the case in Tel Aviv). Officials readily admit that they also see the course as a potential source of income for the financially troubled Technion, which will be able to accept overseas students and their tuition fees without investing money in new facilities.

A similar scheme is on the agenda at the newly established Korat School of Veterinary Medicine of the Hebrew University. Its director, Professor Kalman Perk, expects an annual intake of 30 students, half Israeli and half foreign. But the programme will begin only in two years' time, after the opening of a veterinary hospital near the campus and after the first veterinary school class has graduated.

Unlike Tel Aviv University and Technion, overseas participants in the Hebrew University scheme will be expected, after the first year, to attend regular Hebrewlanguage classes.
Nechemia Meyers 